\title{
POPULATION ECOLOGY OF PAEPALANTHUS POLYANTHUS: PREDISPERSAL HAZARDS AND SEED PRODUCTION ${ }^{1}$
}

\author{
Tânia Tarabini Castellani² \\ Fernanda Faraco d'Eça-Neves ${ }^{3}$
}

Recebido em 16/06/1998. Aceito em 03/05/2000

\begin{abstract}
RESUMO - (Ecologia populacional de Paepalanthus polyanthus: riscos de pré-dispersão e produção de sementes). Este estudo visou avaliar a produção de sementes e os riscos de pré-dispersão em uma população de $P$. polyanthus (Eriocaulaceae) em dunas costeiras no sul do Brasil. O mal desenvolvimento de capítulos florais foi causado pelo vento e por interferência entre umbelas. Correlação positiva entre a proporção de capítulos atrofiados e o número de capítulos/umbela sugere certa limitação de recursos. A lagarta de uma espécie de Recurvaria Haworth (Lepidoptera: Gelechiidae) que se alimenta de flores, e a lagarta de um brocador (Lepidoptera não identificado) foram os principais herbívoros. Plantas que reproduziram durante o pico de floração tiveram menor probabilidade de serem danificadas pelas lagartas de Recurvaria sp., sugerindo escape à herbivoria por sincronismo na floração. A proporção de capítulos danificados por herbívoros foi baixa, causando redução de 5\% na produção total de sementes/planta. O lepidóptero brocador pode causar ou não o aborto de umbela. Na ocorrência deste aborto ocorre redução de $12 \%$ na produção de sementes. Muitos capítulos não danificados e flores individuais (acima de 50\%) não produziram sementes. Falhas na polinização podem estar relacionadas com esta baixa produção de sementes. É discutido que o baixo recrutamento de plântulas observado na população de $P$. polyanthus não parece ser limitado pela chuva de sementes, sendo estimada produção média de 8.000 sementes/planta mesmo sob o efeito de herbivoria.
\end{abstract}

Palavras-chave - Paepalanthus polyanthus, herbivoria, produção de sementes, pré-dispersão, dunas

ABSTRACT - (Population ecology of Paepalanthus polyanthus: predispersal hazards and seed production). This study aimed at evaluating seed production and predispersal hazards in a sand dune population of $P$. polyanthus (Eriocaulaceae) in Southern Brazil. Bad development of flowering capitula was caused by the wind and by interference among umbels. A positive correlation between the proportion of atrophied capitula and the number of capitula/ umbels also suggested resource limitation. A caterpillar of a Recurvaria Haworth (Lepidoptera: Gelechiidae) species that eats flowers and a boring caterpillar (Lepidoptera not identified) were the main herbivores. Plants reproducing during the flowering peak had a lower probability of being damaged by Recurvaria sp., suggesting an escape from herbivores by flowering synchronism. The proportion of capitula damaged by herbivores was low, causing a reduction of about $5 \%$ in the seed set/plant. The boring caterpillar may or may not cause umbel abortion. When the abortion occurs, seed production is reduced by $12 \%$. Many capitula with no damage and individual flowers (up to $50 \%$ ) did not produce seeds. Pollination failure could be related to this low rate of seed set. We discuss the fact that

1 Financial support was provided by grants from DAP/UFSC and CNPq

2 Departamento de Ecologia e Zoologia, CCB, Universidade Federal de Santa Catarina, C. Postal 476, CEP 88040-900, Florianópolis, SC, Brazil

3 Departamento de Botânica, IB, UNESP, C. Postal 199, CEP 13506-900, Rio Claro, SP, Brazil 
the low recruitment of seedlings reported for populations of $P$. polyanthus did not seem to be limited by seed rain, which was estimated at an average of 8000 seeds/plant even when herbivore damage occurred.

Key words - Paepalanthus polyanthus, herbivory, seed production, predispersal hazards, sand dune slack

\section{Introduction}

Insufficient pollination, resource deficiency, predation, and development failure due to deleterious genetic combinations are the main causes of mortality of ovules and seeds during the predispersal phase (Stephenson 1981; Lee \& Bazzaz 1982; Bawa \& Webb 1984; Fenner 1985). Flower and seed predation before dispersal reduces seedling recruitment in coastal environments and in prairies (Louda 1982; Louda et al. 1990). Herbivores on flowering stems decreased the number of capitula and the density in a sand dune population of Cirsium vulgare (Savi) Ten. (Compositae) (Klinkhamer et al. 1988). In Vulpia fasciculata (Forskal) Samp. (Gramineae), grazing on developing inflorescence may cause plant death and reduce the seed rain (Watkinson \& Harper 1978). Flower, fruit and seed predation in the predispersal phase have been described for other sand dune plants, and the importance of these factors for seedling recruitment has often been discussed in the literature (Wilson 1977; Sterk et al. 1982; Zedler et al. 1983; van Groenendael 1986; Costa et al. 1991).

Paepalanthus polyanthus (Bong.) Kunth (Eriocaulaceae) is a monocarpic species, found in sand dunes in Southern Brazil. Populations of this plant undergo periods of marked local reduction due to the low emergence of seedlings without reposition of dead reproductive plants. Expressive seedling recruitment occurs in years of high rainfall, suggesting some dependence of germination and seedling survival on the water available (Castellani et al. 1995a, b).

In this study, our objective was to estimate the seed production of $P$. polyanthus and to evaluate the factors that reduce seed production during the predispersal phase. Since in other plant species abortion and the flower-and-seed predation rate may vary with the size of reproductive structures (Fenner 1985, Santos et al. 1992), and since the predation rate may be influenced by synchronisation of flowering and fruiting within the population (Janzen 1971, Silvertown 1980, Augspurger 1981, Santos et al. 1992), we also evaluated the importance of these factors in relation to $P$. polyanthus.

\section{Materials and methods}

Studied species - In Santa Catarina State, Brazil, Paepalanthus polyanthus (Fig. 1A) occurs in upland fields and coastal sand dunes. This is a monoecious species, presenting umbels with hundreds of capitula of male and female flowers (Moldenke \& Smith 1976). In sand dunes, $P$. polyanthus can reproduce in the second year of life, or later, and is described as a short-lived monocarpic perennial plant (Castellani et al. 1995b). This species flowers from July to January, with a flowering peak in November. The fruiting period begins in September, with a peak in December (d'Eça Neves \& Castellani 1994). The average number of umbels per plant was described as around 14 in 1988, 10 in 1989 and 8 in 1990, a positive correlation occurring between the number of umbels produced and the rosette diameter (Castellani 1990; d'Eça Neves \& Castellani 1994). The flowering of umbels is synchronised within the plant, with the anthesis of male flowers occurring first, followed by female flowers and male flowers again (d'Eça Neves \& Castellani 1994).

Study area - This study was carried out in a $450 \mathrm{~m}^{2}$ plot, located $500 \mathrm{~m}$ from the sea in a sand dune slack at Joaquina Beach (27'36'40'S and $\left.48^{\circ} 27^{\prime} 10^{\prime \prime} \mathrm{W}\right)$, Santa Catarina State, Brazil. The 

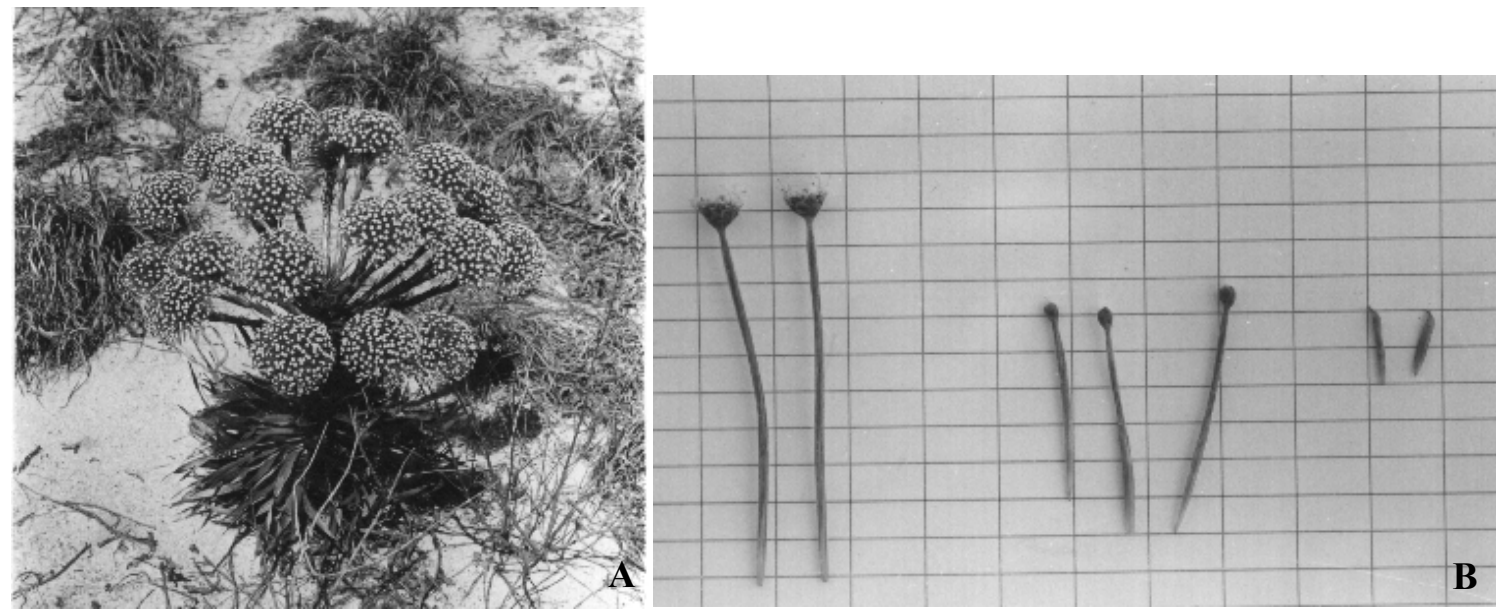

Figure 1: A) Paepalanthus polyanthus plant showing the capituliform umbel and B) developed capitula (left), atrophied capitula not enclosed by the capitulum stem sheath (middle) and enclosed by the sheath (right). Scale: $6 \mathrm{~mm} 3 \mathrm{~mm}$.

local climate is characterised as $\mathrm{Cfa}$ mesothermic, according to Köppen (Souza et al. 1992). Rainfall occurs all year round, with higher indices in January and February, and lower precipitation from June to August (Castellani et al. 1999). During the study year (1990), the lowest average temperature occurred in June $\left(14.5^{\circ} \mathrm{C}\right)$, and the highest in February $\left(24.8^{\circ} \mathrm{C}\right)$. Rainfall distribution followed the above pattern, the total annual precipitation being $1941 \mathrm{~mm}$ (DEPV-FL, Florianópolis, SC). The predominant winds at Joaquina Beach are those from both Northern and Southern directions (Santos et al. 1995).

Agents inhibiting reproduction - A total of 123 plants began reproduction in the plot. These were marked and periodically checked to determine their reproductive phenological phases defined as: bud (umbels with closed and developing capitula), flowering (capitula with female or male flowers opening), and fruiting (capitula with developing seeds until dispersal began). For each sample, the umbels of each plant were counted and checked for the presence of herbivores and other damaging agents. Damaged umbels were marked and observed until dispersal.

Pupas of the two main herbivores associated with $P$. polyanthus inflorescences were collected in capitula, or entire umbels, and kept in containers under laboratory conditions until adult emergence. The adults obtained were identified by Dr. Vitor O. Becker (EMBRAPA/DF, Brazil).

Capitula production and damage - During the reproductive season, 152 fruiting umbels were collected before dispersal. In the laboratory, capitula were classified as: 1) developed; 2) developed with damage due to herbivores; and 3 ) atrophied. The atrophied capitula were classified as enclosed or not enclosed by the capitulum stem sheath (Fig. 1B). The number of capitula in each class was recorded.

Flower and seed production - In the fruiting plants, no flowers or seeds fell from the capitula. Utilising a stereoscopic microscope (Wild Leitz M3Z), $1 \%$ of the developed capitula damaged and $1 \%$ not damaged by herbivores were analysed to determine the number of male and female flowers/capitulum and the number of seeds/flower. Female flowers were quantified according to the occurrence of anthesis, the number that initiated seed formation, and those that produced seeds.

Statistical treatment - The occurrence of 
herbivore damage in plants with different numbers of umbels and the occurrence of plants damaged during the flowering season were analysed by G-test (Sokal \& Rohlf 1969). The Spearman rank correlation (Zar 1974) was applied to test relationships between the proportions of damaged plants, damaged capitula or atrophied capitula, and the number of reproductive structures.

Comparisons of flower and seed production in capitula with and without herbivore damage were done by the use of Mann-Whitney U tests. In calculations of significance, normal approximation was used, obtaining the $\mathrm{Z}$-value, following the procedures suggested for tied rank data (Zar 1974).

The proportions of flowers that maturated seeds in developed capitula and in capitula damaged by herbivores were estimated. A comparison of these proportions was carried out using a $2 \times 2$ contingency table, considering proportions and calculating the Z-value with correction for continuity (Zar 1974).

\section{Results}

Herbivores and percentage of plants damaged throughout the reproductive season The caterpillars of two Lepidoptera species were the main herbivores damaging the reproductive structures of $P$. polyanthus. Caterpillars of a Recurvaria Haworth (Lepidoptera: Gelechiidae) species were observed eating flowers. These caterpillars, about $5 \mathrm{~mm}$ in length and creamcoloured, also use individual flowers adhered to the body for camouflage. Damage by this species was observed in $59(47.97 \%)$ of the 123 monitored plants, and occurred in 197 (23.71\%) of the 831 umbels produced. The Recurvaria sp. caterpillars were observed on flowering plants, but they were registered only once on plants in the budding phase (Fig. 2 A, B). In fruiting plants, Recurvaria sp. were registered in pupa or in the last larval instar.

The frequency of flowering plants damaged by Recurvaria sp. was significantly different during the flowering season (G-test 15.12, gl=7;
$\mathrm{P}<0.05)$. Plants flowering during peak blooming (November) showed a lower probability of being damaged by these caterpillar species (Fig. 2B). Therefore, a negative correlation between the percentage of plants damaged and the number of plants in flower was found (Fig. 3). The occurrence of damage caused by Recurvaria sp. was independent of the number of umbels/ plant (G-test=5.69, gl=5, P>0.05) (Fig. 4).

The other Lepidoptera observed was a boring caterpillar. Since no adults emerged from the pupas kept in the laboratory, this species could not be identified. The boring caterpillar damaged the base and stem of the umbels, causing umbel abortion or loss of the individual capitula. Damage by this Lepidoptera species was observed in 28 plants $(22.76 \%)$, with umbel abortion in 10 $(8.13 \%)$. The boring caterpillar was observed from the budding phase onwards, and was mostly recorded in flowering plants (Figs. 2A, B). The frequency of plants damaged by this species did

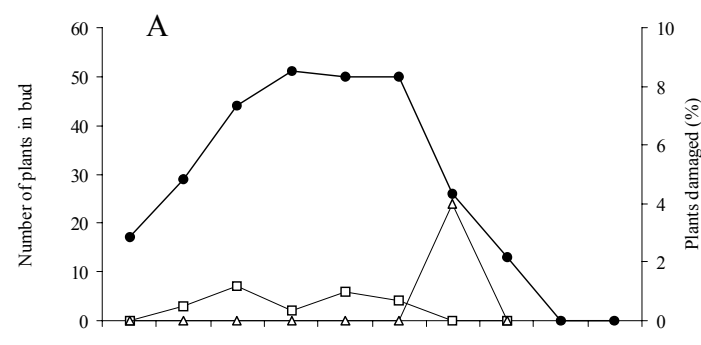

B

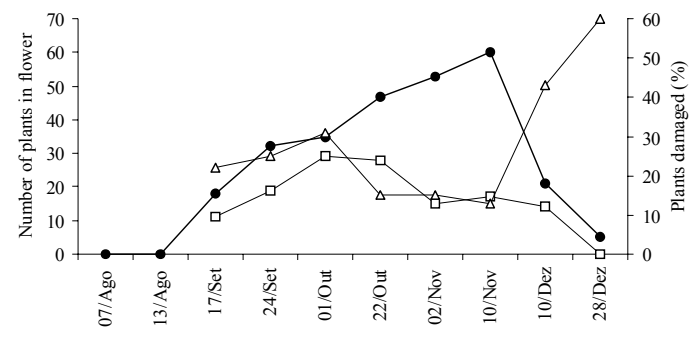

Figure 2. Number of Paepalanthus polyanthus plants present in $450 \mathrm{~m}^{2}$ in different phenological phases $\left({ }^{\bullet}\right)$ and percentage of plants damaged by Recurvaria sp. caterpillar $(\triangleright)$ and damaged by borer caterpillar $(\bullet)$ : A) plants in bud, (B) plants in flower. 


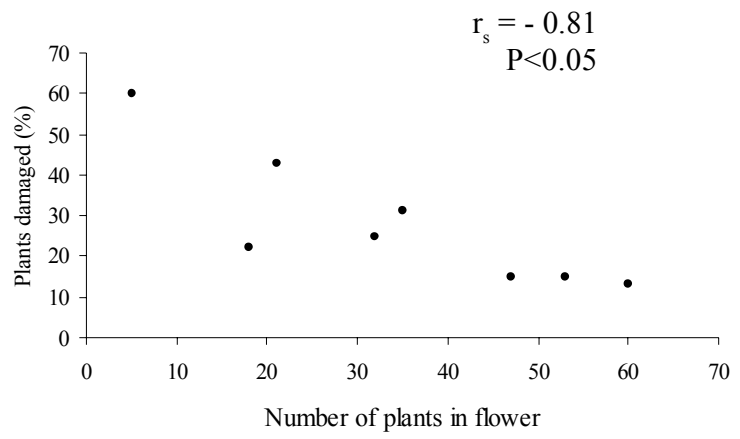

Figure 3. Percentage of plants damaged by Recurvaria sp. caterpillar in relation to the number of flowering plants in $450 \mathrm{~m}^{2} . \mathrm{r}_{\mathrm{s}}$ : Spearman's rank correlation coefficient.

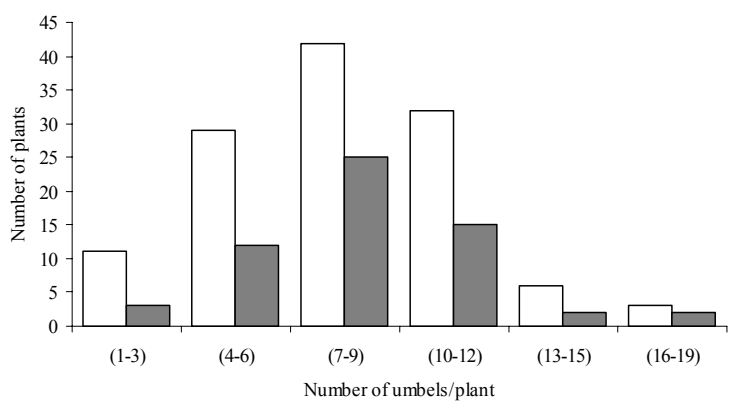

Figure 4. Number of Paepalanthus polyanthus plants present in different classes of umbels produced (white) and number of plants damaged by the Recurvaria $\mathrm{sp}$. caterpillar (grey).

not differ during the flowering season (G-test= 7.98, gl=7, $\mathrm{P}>0.05$ ) (Fig. 2B). This caterpillar pupates among capitula in flowering and fruiting plants.

Production of flowering capitula and loss by bad development and herbivores - Paepalanthus polyanthus umbels produced an average of 290 flowering capitula of which $62.42 \%$ were fully developed, having suffered no damage by herbivores (Tab. 1), as described below.

About $29 \%$ of the capitula did not develop (Tab. 1). A positive correlation between the proportion of atrophied capitula/umbel and the total number of capitula/umbel $(\mathrm{r}=0.25$; $\mathrm{P}<0.002 ; \mathrm{n}=152$ ) was observed. Wind action caused desiccation, abrasion and atrophy of capitula in 36 plants $(29.27 \%$ ) affecting 234 umbels $(28.16 \%)$. Part of the capitula of these umbels was atrophied, especially those exposed to the south wind (Fig. 5). Overlapping umbels also presented undeveloped capitula. Many capitula which were in mutual contact did not open. This fact was observed in 8 plants $(6.5 \%)$ and 22 umbels $(2.65 \%)$.

Among the 152 collected umbels, 134 were damaged by the caterpillars. Herbivores affected $8.36 \%$ of the total production of capitula/umbel (Tab. 1). The proportion of capitula damaged by herbivores did not show a significant correlation with the number of capitula developed/umbel $\left(r_{\mathrm{s}}=0.0016 ; \mathrm{P}>0.50 ; \mathrm{n}=152\right)$.

Production of flowers and seeds and rates of loss by herbivores and other factors Averages of 15.25 male flowers ( $\mathrm{std}=6.04$;

Table 1. Flowering capitula/umbel ( $n=152$ umbel) of Paepalanthus polyanthus and their fates: developed capitula, atrophied capitula and developed capitula damaged by herbivores. The percentages $(\%)$ are relative to the total number of capitula produced/umbel. Std=standard deviation.

\begin{tabular}{lrrr}
\hline & Mean & (Std) & $(\%)$ \\
\hline Total number of capitula/umbel & 290.08 & $(121.69)$ & 100 \\
Number of atrophied capitula/umbel & 84.78 & $(49.91)$ & 29.23 \\
- capitula enclosed & 13.57 & $(21.25)$ & 4.68 \\
- capitula not enclosed by the & & & \\
$\quad$ capitulum stem sheath & 71.21 & $(47.73)$ & 24.55 \\
Number of developed capitula/umbel & 205.30 & $(105.02)$ & 70.77 \\
- capitula not damaged by herbivores & 181.06 & $(96.22)$ & 62.42 \\
- capitula damaged by herbivores & 24.24 & $(31.50)$ & 8.36 \\
\hline
\end{tabular}

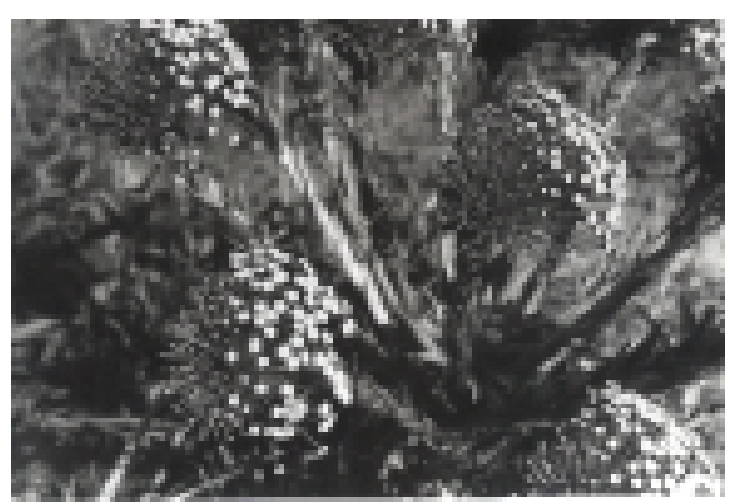

Figure 5. Umbel of Paepalanthus polyanthus damaged by wind. Note the atrophied capitula on the left. 
min. $=0$ and $\max .=33 ; n=274), 5.47$ female flowers $(\mathrm{std}=2.25 ; \min .=0$ and $\max .=15 ; \mathrm{n}=274)$ and 5.35 developed seeds $(\mathrm{std}=5.18 ; \min .=0$ and max. $=22 ; n=274$ ), were produced per developed capitulum. Among female flowers, $6.3 \%$ did not reach anthesis. Many flowers reached anthesis but did not initiate fruit formation, and some aborted seeds in initial development. Only 46.6\% of the flowers produced seeds. From the 1740

Table 2. Success of flowering and rate of seed maturation in female flowers of Paepalanthus polyanthus in developed capitula. The percentages (\%) were calculated in relation to the 1498 flowers surveyed in 274 capitula from 152 umbels.

\begin{tabular}{lc}
\hline Total of flowers analysed & 1498 \\
Flowers that did not reach floral anthesis (\%) & 6.30 \\
$\begin{array}{l}\text { Flowers that reached floral anthesis but did not } \\
\text { initiate fructification (\%) }\end{array}$ & 43.72 \\
Flowers that initiated fructification but did not & \\
mature seeds (\%) & 3.34 \\
Flowers that initiated fructification and mature & \\
seeds (\%) & 46.60 \\
- flowers that produced 1 mature seed (\%) & 13.42 \\
- flowers that produced 2 mature seeds (\%) & 14.09 \\
- flowers that produced 3 mature seeds (\%) & 18.09 \\
Total of seeds that initiated development & 1740 \\
- mature seeds (\%) & 84.25 \\
- seeds badly developed (\%) & 15.75 \\
\hline
\end{tabular}

seeds that initiated development, $15.75 \%$ showed a rudimentary growth (Tab. 2).

Herbivores on flowering capitula significantly reduced the number of male and female flowers per capitulum (Tab. 3; Fig. 6). The frequency of capitula with no female flower increased from $0.75 \%$ to $11.0 \%(n=134)$ when herbivores occurred; capitula with no male flower increased only from $0.75 \%$ to $2.24 \%$ $(\mathrm{n}=134)$. The reduction in flower numbers (about 23-29\%) contributed to a significant reduction in seed production (about 46\% less) (Tab. 3; Fig. 7). The occurrence of capitula with no seed set increased from $23.13 \%$ to $36.56 \%(n=134)$. It was observed that damaged capitula presented a higher proportion of flowers that reached anthesis but did not initiate seed development, thus significantly reducing the number of female flowers that produced mature seeds (Tab. 4) $(Z=3.32$; $\mathrm{P}<0.001)$. Male flowers in damaged capitula were also affected, exhibiting $6.28 \%$ of chewed flowers and $4.02 \%$ of loose flowers ( $n=1639)$.

Despite herbivore action it was observed that a high number of developed capitula in $P$. polyanthus did not produce seeds (Fig. 7; Tab. 2, 4).

Production of seeds per plant - Based on

Table 3. Comparison of the male and female flower production and seed set per developed capitulum damaged and undamaged by herbivores. Values of $Z$ and $\mathrm{P}$ in the Mann-Whitney U-test using normal approximation. Rates of reduction $(\%)$ were calculated by: (number presented on damaged - undamaged capitula / number in undamaged capitula) x 100 .

\begin{tabular}{|c|c|c|c|c|}
\hline & $\begin{array}{l}\text { Undamaged by herbivores } \\
\text { Mean (std) } \\
\text { (min-max) }\end{array}$ & $\begin{array}{l}\text { Damaged by herbivores } \\
\text { Mean (std) } \\
\text { (min-max) }\end{array}$ & $\mathrm{Z}$ & $\mathrm{P}$ \\
\hline $\begin{array}{l}\text { Number of male flowers/developed capitulum } \\
\text { - rate of reduction }=22.64 \%\end{array}$ & $\begin{array}{c}15.81(6.02) \\
(0-33)\end{array}$ & $\begin{array}{c}12.23(6.79) \\
(0-28)\end{array}$ & 4.40 & $<0.001$ \\
\hline $\begin{array}{l}\text { Number of female flowers/developed capitulum } \\
\text { - rate of reduction }=28.97 \%\end{array}$ & $\begin{array}{c}5.66(2.25) \\
(0-15)\end{array}$ & $\begin{array}{c}4.02(2.77) \\
\quad(0-13)\end{array}$ & 5.46 & $<0.001$ \\
\hline $\begin{array}{l}\text { Number of seed sets/developed capitulum } \\
\text { - rate of reduction }=46.17 \%\end{array}$ & $\begin{array}{c}5.61(5.39) \\
(0-22)\end{array}$ & $\begin{array}{c}3.02(3.46) \\
\quad(0-16)\end{array}$ & 3.90 & $<0.001$ \\
\hline Number of capitula analysed & 134 & 134 & & \\
\hline
\end{tabular}



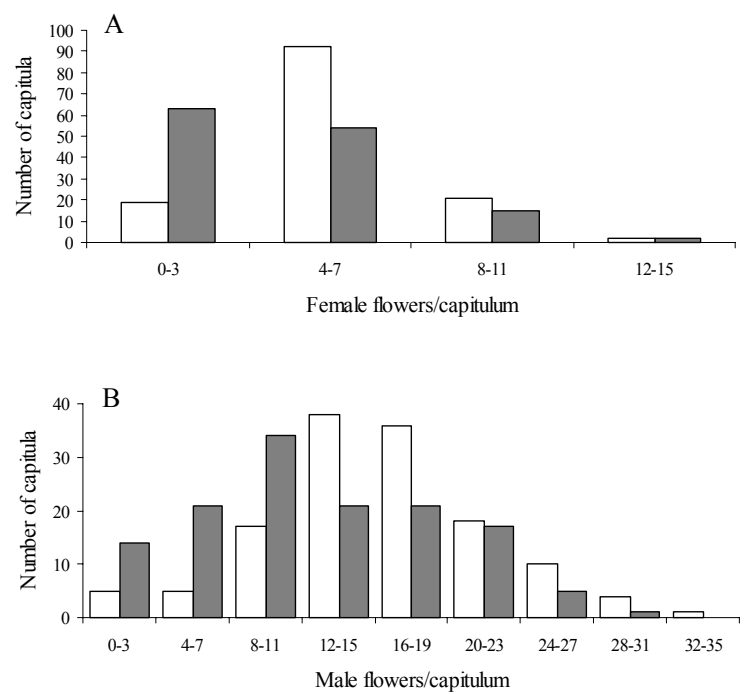

Figure 6. Number of female (A) and male flowers (B) of Paepalanthus polyanthus presented in developed capitula damaged (grey) and not damaged (white) by herbivores.

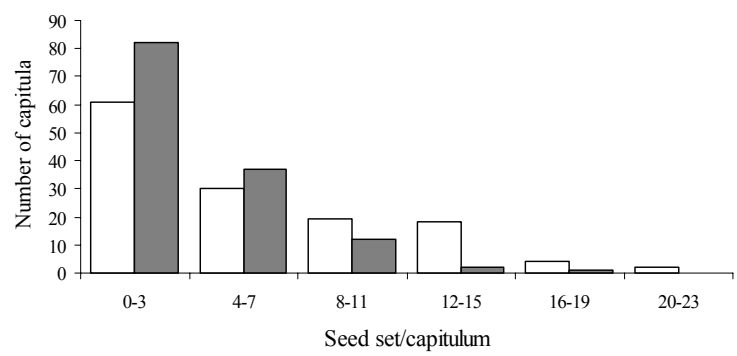

Figure 7. Number of seeds of Paepalanthus polyanthus produced in developed capitula damaged (grey) and not damaged (white) by herbivores.

an average production of 205.30 developed capitula/umbel and a production of 5.61 seeds/ developed capitulum, approximately 1152 seeds/ umbel were expected in the absence of herbivores. Based on an average of 8.03 umbels/ plant in the year 1990 (d'Eça Neves \& Castellani 1994), a plant with no herbivore damage could produce about 9248 seeds. Assuming an average of 24.24 capitula damaged by herbivores and a production of 3.02 seeds/capitulum damaged, an umbel would produce 1089 seeds. A plant with this level of damage in all umbels would produce 8744 seeds, nearly $5.45 \%$ less than the produc- tion expected without herbivores. Seeing that the boring caterpillar can cause umbel abortion, a greater loss in seed production could occur. In 1990, we did not observe more than one aborted umbel/plant; therefore, we were able to estimate that in an average plant ( 8 umbels) this damage would generate a reduction to 8097 seeds, approximately $12.45 \%$ less than that estimated for a plant without herbivores.

\section{Discussion}

Paepalanthus polyanthus can produce hundreds of capitula/umbel, but about $40 \%$ are affected by faulty development or herbivore attack.

Three factors may be involved as causes of atrophied capitula in $P$. polyanthus: wind, resource deficiency and mechanical interference among umbels. Wind causes desiccation and atrophy of capitula in $P$. polyanthus affecting flower production in about one-third of the population. Although the influence of the wind on the vegetative development of plants in coastal zones is usually mentioned (Daubenmire 1974; Etherington 1982), the studies on seed production and predispersal hazards in sand dunes (Watkinson \& Harper 1978; Sterk et al. 1982; Zedler et al. 1983; Westelaken \& Maun 1985; van Groenendael 1986; Klinkhamer et al. 1988; Costa et al. 1991) do not refer to wind effect on the development of reproductive structures. Nevertheless, wind action is reported by Lee \& Bazzaz (1982) as an abiotic factor which may cause the loss of young fruits or seeds.

Indirect evidence suggests that some limitation of resources influences the full development of capitula in $P$. polyanthus. A positive relationship between abortion rate and the size of inflorescence is indirect evidence for resource limitation (Stephenson 1980 apud Fenner 1985; Santos et al. 1992) and in $P$. polyanthus such a correlation was significant. The high number of developed capitula with no seeds does not seem to be explained by failure in seed maturation; many flowers reached 
Table 4. Success of flowering and rate of seed maturation in female flowers of Paepalanthus polyanthus in developed capitula damaged and undamaged by herbivores. The percentages were calculated in relation to the total number of flowers present in the capitula analysed ( $n=134$ damaged and 134 undamaged).

\begin{tabular}{|c|c|c|}
\hline & $\begin{array}{l}\text { Undamaged } \\
\text { by herbivores }\end{array}$ & $\begin{array}{r}\text { Damaged by } \\
\text { herbivores }\end{array}$ \\
\hline Total flowers analysed in 134 capitula & 759 & 539 \\
\hline Flowers that did not reach floral anthesis (\%) & 6.19 & 8.26 \\
\hline Flowers that reached floral anthesis but did not initiate fructification (\%) & 41.24 & 48.79 \\
\hline Flowers that initiated fructification but did not mature seeds (\%) & 4.47 & 3.52 \\
\hline Flowers that initiated fructification and mature seeds (\%) & 48.09 & 38.96 \\
\hline - flowers that produced 1 mature seed $(\%)$ & 14.23 & 15.21 \\
\hline - flowers that produced 2 mature seeds (\%) & 16.73 & 11.32 \\
\hline - flowers that produced 3 mature seeds (\%) & 17.13 & 12.43 \\
\hline Total of seeds that initiated development & 838 & 428 \\
\hline - mature seeds $(\%)$ & 89.74 & 94.62 \\
\hline - seeds badly developed (\%) & 10.26 & 5.38 \\
\hline
\end{tabular}

anthesis but did not initiate seed development. This fact may suggest a pollination failure. D'Eça Neves \& Castellani (1994) suggest a dependence on pollination agents in $P$. polyanthus reproduction, and the visiting rate in this plant being low (Vera L. V. De Arruda, pers. comm.). In other sand dune species, low rates of fruit and seed production are related to the inefficiency of pollination and/or limitation of resources (Sterk et al. 1982; Zedler et al. 1983; Westelaken \& Maun 1985; Cordazzo \& Davy 1994).

Some hypotheses related to damage may also be discussed. Excessive reproductive structures could substitute those that are damaged or lost through predation (Lee \& Bazzaz 1982) and may also help to satiate herbivores (Zedler et al. 1983). For P. polyanthus, a significant relationship between the rate of damaged capitula by herbivores and the number of capitula developed/umbel was not found. Nevertheless, the proportion of plants damaged by Recurvaria sp. tended to be lower during the flowering peak. This suggests that a synchronism within flowering plants could provide an escape from some herbivores. Zimmerman (1980) reports higher predation rates in seeds of Polemonium foliosissimum Gray (Polemoniaceae) at the beginning of the reproductive season. Plants of Hybanthus prunifolius (Schult.) Schulze (Violaceae), which flower synchronously, suffer less herbivore damage than those which flower asynchronously (Augspurger 1981). In Ipomoea cf. grandifolia (Dammer) O'Donell (Convolvulaceae), a reduction in the rate of fruit predation occurs during fruiting peaks (Santos et al. 1992). Reduction in predation rates, with synchronism of the population, may reflect satiation effects at moments of higher production (Janzen 1971; Silvertown 1980).

The action of herbivores on reproductive structures of $P$. polyanthus did not cause a representative loss in total seed production. Although the production of seeds/capitulum damaged is reduced by $50 \%$, the average proportion of damaged capitula is low in the population. The frequency of umbel abortion is also low.

In relation to other sand dune plants, Cirsium 
rhothophilum Blake (Compositae) lost $25 \%$ of achene production due to insect herbivores (Zedler et al. 1983). In Cirsium vulgare (Savi) Ten. (Compositae), the loss due to damage in flowering capitula was of $3 \%$ and $17 \%$. However, predation on stem flowering reduced the production of seeds by $80 \%$ and $15 \%$ thus diminishing seedling recruitment and population density (Klinkhamer et al. 1988). In Vulpia fasciculata (Forskal) Samp. (Gramineae), the reduction in seed production due to herbivores was from 4 to $31 \%$, thus decreasing the seed rain (Watkinson \& Harper 1978). Nevertheless, Keddy et al. (1983) considered that predation of flowers and seeds of Cypripedium passerinum Rich. (Orchidaceae) did not affect population recruitment; the emergence of seedlings was rare and dependent on humidity. Loss in seed production of a $P$. polyanthus plant damaged by predation was estimated at $5 \%$, and was $12 \%$ in the case of umbel abortion by boring caterpillars. These low values observed in 1990 suggest that herbivore action in the predispersal phase is not a limiting factor to seedling recruitment in this population. Castellani et al. (1995a, b) refer to soil moisture as an important factor limiting regeneration, showing differences in the emergence of seedlings between years with different precipitation, and between areas with different distances from the water table.

\section{Acknowledgements}

We are grateful to Vera Lícia Vaz de Arruda and Benedito Cortês Lopes for suggestions regarding the study and comments on the manuscript, and two anonymous reviewers for critical suggestions.

\section{References}

Augspurger, C. K. 1981. Reproductive synchrony of a tropical shrub: experimental studies of pollinators and seed predators on Hybanthus prunifolius (Violaceae). Ecology 62(3): 775-788.

Bawa, K. S. \& Webb, C. J. 1984. Flower, fruit and seed abortion in tropical forest trees: implications for the evolution of paternal and maternal reproductive patterns. American Journal of Botany 71(5): 736-751.

Castellani, T. T. 1990. Aspectos da ecologia reprodutiva de Paepalanthus polyanthus (Bong.) Kunth (Eriocaulaceae) nas dunas da Joaquina, Ilha de Santa Catarina, SC. Pp. 488-498. In II Simpósio de Ecossistemas da Costa Sul e Sudeste Brasileira: estrutura, função e manejo, Águas de Lindóia 1990. ACIESP Ed. V. 3, São Paulo.

Castellani, T. T.; Folchini, R. \& Scherer, K. Z. 1995a. Variação temporal da vegetação em um trecho de baixada úmida entre dunas, praia da Joaquina, Florianópolis, SC. Ínsula 24: 37-72.

Castellani, T. T.; Scherer, K. Z. ; Locatelli, L. M. \& Lopes, B. C. 1995b. The occurrence of Junonia evarete (Lepidoptera: Nymphalidae) and Acromyrmex striatus (Hymenoptera: Formicidae) on Paepalanthus polyanthus (Eriocaulaceae). Journal of the New York Entomological Society 103(3): 129-334.

Castellani, T. T.; Caus, C. A. \& Vieira, S. 1999. Fenologia de uma comunidade de duna frontal no sul do Brasil. Acta Botanica Brasilica 13(1): 99 114.

Cordazzo, C. V. \& Davy, A. J. 1994. Seed production and seed quality of the dune building grass Panicum racemosum Spreng. Acta Botanica Brasilica 8(2): 193-203.

Costa, C. S. B.; Seeliger, U. \& Cordazzo, C. V. 1991. Leaf demography and decline of Panicum racemosum populations in coastal foredunes of southern Brazil. Canadian Journal of Botany 69: 1593-1599.

Daubenmire, R.F. 1974. Plants and Environment. John Wiley \& Sons, New York.

d'Eça Neves, F. F. \& Castellani, T. T. 1994. Fenologia e aspectos reprodutivos de Paepalanthus polyanthus (Bong.) Kunth (Eriocaulaceae) em baixada úmida entre dunas na Praia da Joaquina, Ilha de Santa Catarina, SC. Ínsula 23: 121-149.

Etherington, J. R. 1982. Environment and Plant Ecology. John Wiley \& Sons, New York.

Fenner, M. 1985. Seed Ecology. Chapman and Hall, New York.

Janzen, D. H. 1971. Seed predation by animals. Annual Review Ecology and Systematics 2: 465-492.

Keddy, C. J.; Keddy, P. A. \& Planck, R. J. 1983. An ecological study of Cypripedium passerinum Rich. (Sparrow's egg lady-slipper, Orchidaceae) on the north shore of Lake Superior. Canadian Field-Naturalist 97(3): 268-274.

Klinkhamer, P. G.; De Jong, T. J. \& van der Meijden, E. 1988. Production, dispersal and predation of seeds 
in the biennial Cirsium vulgare. Journal of Ecology 76: 403-414.

Lee, T. D. \& Bazzaz, F. A. 1982. Regulation of fruit set and production in an annual legume, Cassia fasciculata. Ecology 63(5): 1363-1373.

Louda, S. M. 1982. Limitation of the recruitment of the shrub Haplopappus squarrosus (Asteraceae) by flower and seed-feeding insects. Journal of Ecology 70: 43-53.

Louda, S. M.; Potvin, M. A. \& Collinge, S. K. 1990. Predispersal seed predation, postdispersal seed predation and competition in the recruitment of seedlings of a native thistle in sandhills prairie. American Midland Naturalist 124: 105-113.

Moldenke, H.N. \& Smith, L.S. 1976. Eriocauláceas. Pp. 1-94. In R. Reitz (Ed.), Flora Ilustrada Catarinense. Herbáreo Barbosa Rodrigues, Itajaí.

Santos, C. R.; Bayer, L. L \& Castellani, T. T. 1992. Visitantes florais e riscos de pré-dispersão em uma espécie de Ipomoea (Convolvulaceae), Florianópolis, SC. Biotemas 5(1): 91-106.

Santos, C. R.; Castellani, T. T. \& Horn Filho, N. O. 1995. Aspects of the dune "pioneer" vegetation dynamics at the beach and fore dune regions at Joaquina Beach, Santa Catarina Island, Brazil. Pp. 70-71. In Scientific Meeting Land-ocean interactions in coastal zone, 1995. LOICZ/IGBP Ed, São Paulo.

Silvertown, J. W. 1980. The evolutionary ecology of mast seeding in trees. Biological Journal of the Linnean Society 14: 235-250.

Sokal, R. S. \& Rohlf, F. G. 1969. Biometria. H. Blume Ediciones, Madrid.

Souza, M. L. R.; Falkemberger, D. B.; Amaral, L. A.; Fronza, M.; Araujo, A. C. \& Sá, M. R. 1992. Vegetação do Pontal da Daniela, Florianópolis, SC, Brasil. I. Levantamento florístico e mapa fitogeográfico. Ínsula 21: 7-117.

Stephenson, A. G. 1981. Flower and fruit abortion: proximate causes and ultimate functions. Annual Review of Ecology and Systematics 12: 253-279.

Sterk, A. A.; Duijkaren, A.; van Hogervorst, J. \& Verbeek, E. D. M. 1982. Demographic studies of Anthyllis vulneraria L. in the Netherlands. II. Population density fluctuations and adaptations to arid conditions, seed populations, seedling mortality, and influence of the biocenosis on demographic features. Acta Botanica Neerlandica 31(1/2): 11-40.

van Groenendael, J. M. 1986. Life history characteristics of two ecotypes of Plantago lanceolata L. Acta Botanica Neerlandica 35(2): 71-86.
Watkinson, A. R. \& Harper, J. L. 1978. The demography of a sand dune annual: Vulpia fasciculata. I: The natural regulation of populations. Journal of Ecology 66: 15-33.

Westelaken, I. L. \& Maun, M. A. 1985. Reproductive capacity, germination and survivorship of Lithospermum caroliniense on Lake Huron sand dunes. Oecologia 66: 238-245.

Wilson, D. E. 1977. Ecological observations on the tropical strand plants Ipomoea pes-caprae (L.) R. Br. (Convolvulaceae) Canavalia maritima (Aubl.) Thou (Fabaceae). Brenesia 10/11: 31-42.

Zar, J. H. 1974. Bioestatistical Analysis. Prentice-Hall, Englewood Cliffs.

Zedler, P. H.; Guehlstorff, K.; Scheidlinger, C. \& Gautier, C. R. 1983. The population ecology of a dune thistle, Cirsium rhotophilum (Asteraceae). American Journal of Botany 70(10): 1516-1527.

Zimmerman, M. 1980. Reproduction in Polemonium; pre-dispersal seed predation. Ecology 61(3): 502506. 